Article

\title{
Antiglycation Activity and HT-29 Cellular Uptake of Aloe-Emodin, Aloin, and Aloe arborescens Leaf Extracts
}

\author{
Guglielmina Froldi *(D), Federica Baronchelli, Elisa Marin and Margherita Grison \\ Department of Pharmaceutical and Pharmacological Sciences, University of Padova, 35131 Padova, Italy; \\ fe.baronchelli@gmail.com (F.B.); elisa.marin91@gmail.com (E.M.); margherita.grison@gmail.com (M.G.) \\ * Correspondence: g.froldi@unipd.it; Tel.: +39-049-827-5092; Fax: +39-049-827-5093
}

Received: 19 April 2019; Accepted: 3 June 2019; Published: 5 June 2019

\begin{abstract}
Aloe arborescens is a relevant species largely used in traditional medicine of several countries. In particular, the decoction of leaves is prepared for various medicinal purposes including antidiabetic care. The aim of this research was the study of the antiglycation activity of two $A$. arborescens leaf extracts and isolated compounds: aloin and aloe-emodin. These phytoconstituents were quantitatively assessed in methanolic and hydroalcoholic extracts using high performance liquid chromatography (HPLC) analysis. In addition, the total phenolic and flavonoid contents were detected. In order to study their potential use in diabetic conditions, the antiglycation and antiradical properties of the two extracts and aloin and aloe-emodin were investigated by means of bovine serum albumin (BSA) and 1,1-diphenyl-2-picryl-hydrazil (DPPH) assays; further, their cytotoxicity in HT-29 human colon adenocarcinoma cells was evaluated by 3-[4,5-dimethylthiazol-2-yl]-2,5-diphenyl tetrazolium bromide (MTT) assay. Furthermore, the ability of aloin and aloe-emodin to permeate the cellular membranes of HT-29 cells was determined in order to estimate their potential in vivo absorption. This assessment indicated that aloe-emodin can substantially pass through cell membranes $(\sim 20 \%)$, whereas aloin did not permeate into HT-29 cells. Overall, the data show that both the methanolic and the hydroalcoholic $A$. arborescens extracts determine significant inhibition of glycation and free-radical persistence, without any cytotoxic activity. The data also show that the antiglycation and the antiradical activities of aloin and aloe-emodin are lower than those of the two extracts. In relation to the permeability study, only aloe-emodin is able to cross HT-29 cellular membranes, showing the attitude to pass through the intestinal layer. Overall, the present data surely support the traditional use of $A$. arborescens leaf extracts against hyperglycemic conditions, while aloin and aloe-emodin as potential drugs need further study.
\end{abstract}

Keywords: cellular uptake; BSA assay; MTT assay; DPPH assay; antiglycation activity; plant extracts

\section{Introduction}

Since ancient times, plants have been primary sources of therapeutic preparations; among these, the genus Aloe is generating more and more interest in the scientific field [1,2]. Aloe arborescens Miller (Xanthorrhoeaceae), also known by the common name of "candelabra Aloe", is a traditional medicinal plant native of central-southern Africa, and is very popular in South Africa, Asia, Russia, and Japan as an ornamental and medicinal plant [3]. In Italy, Aloe spp. are cultivated for decorative, cosmetic and medicinal purposes. A. arborescens plants are characterized by a central woody trunk that could reach a height of some meters at maturation. They have branches with bushy shrubs and long, thin, spiny, and grey-green leaves (Supplementary Materials Figure S1). The characteristic components of the red sap are 1,8-dihydroxyanthraquinones and their glycosides, mainly aloe-emodin and aloin, whose 
structures are reported in Figure 1. Further, a large amount of acemannan is present in the inner gel of the leaves [4]. The Aloe genus is known for its traditional use, but the isolated compounds, mainly aloe-emodin, have also been studied as potential conventional drugs. Aloe-emodin has been identified in several species of Aloe and in other genera such as Rheum, Rumex, and Cassia [5]. Aloin is the major anthraquinone of Aloe, which is a mixture of two diastereomers: aloin A (10S) and aloin B (10R) [6]. It is a C-glycoside that in vivo can be hydrolyzed in the gut to form aloe-emodin anthrone, which auto-oxidizes to aloe-emodin [7].

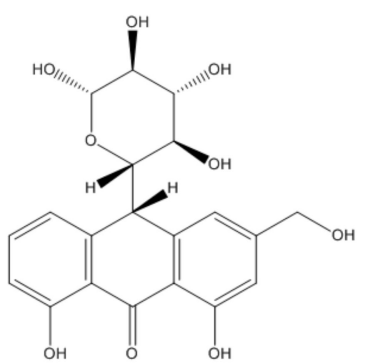

Aloin A (barbaloin)

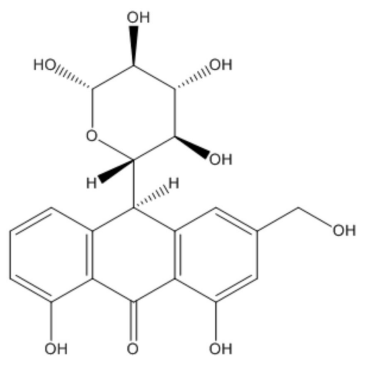

Aloin B (isobarbaloin)

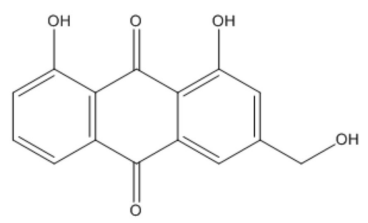

Aloe-emodin

Figure 1. Aloin A, aloin B, and aloe-emodin structures.

Diabetes mellitus (DM) is a metabolic disorder mainly characterized by chronic increase of blood glucose levels. To explain the association between hyperglycemia and the long-term complications of DM, one of the most important mechanisms proposed is the formation of advanced glycation end products (AGEs), which are triggered by endogenous processes related to hyperglycemia and oxidative stress [8]. Since it is known that glycation is accelerated by radical species, the influence of $A$. arborescens extracts, aloin and aloe-emodin on the bovine serum albumin (BSA) glycation and the free-radical persistence was investigated by means of BSA and 1,1-diphenyl-2-picryl-hydrazil (DPPH) assays.

Furthermore, it is interesting to note that $A$. arborescens has been proposed as a palliative therapy in patients with metastatic cancer even in co-administration with the conventional anticancer therapy [9]. In relation to this, the isolated compounds and in particular aloe-emodin have been evaluated in various types of human cancer cell lines where they showed antiproliferative activity [10-12]. This activity was also reported in vivo in various mouse models [13-15]. In general, different studies suggest the pharmacological potential of Aloe extracts and of its isolated compounds, but further studies are required for their actual medicinal use. With this idea, two types of extracts were prepared from the whole leaves of $A$. arborescens, as: (1) a methanolic extract, and (2) a hydroalcoholic extract obtained with ethanol $5 \% v / v$, an alcohol percentage similar to that present in many "drinks" used in unconventional medicine. Thus, the two extracts were firstly assessed detecting their aloin and aloe-emodin amounts with high performance liquid chromatography (HPLC) analysis. Further, the total phenolic and flavonoid contents (TPC and TFC, respectively) were evaluated. Afterwards, the antiglycation and antiradical activities of aloin, aloe-emodin, and of the extracts were investigated and, in order to study the cellular cytotoxicity, their influence on HT-29 human colon adenocarcinoma cells were investigated using the 3-[4,5-dimethylthiazol-2-yl]-2,5 diphenyl tetrazolium bromide (MTT) assay. Lastly, to find answers to the questions: "Are anthraquinones adsorbed by the intestinal layer?" and "Could anthraquinones act in the cells?", the quantities of aloin and aloe-emodin in HT-29 cells and in their culture medium were measured with a suitable experimental protocol.

Thus, the goals of this research were the identification and the quantification of aloe-emodin and aloin in the methanolic and the hydroalcoholic extracts of $A$. arborescens leaves, and the investigation of free-radical scavenging capacities and antiglycation properties of isolated compounds and Aloe leaves extracts. Lastly, the cytotoxicity and the capacity of aloin and aloe-emodin to cross the HT-29 cellular membranes were assessed. 


\section{Results}

\subsection{Methanolic and Hydroalcoholic Extracts: Phytochemical Characterization}

Two extracts of $A$. arborescens were prepared from fresh leaves previously homogenized and lyophilized (yield: $4.8 \pm 0.1 \% p / p$ ). A weighed part of freeze-dry product was soaked in absolute methanol or $5 \% v / v$ ethanol for one hour, and then each solution was filtrated and stored at $4{ }^{\circ} \mathrm{C}$, in the dark, and used within five days. The hydroethanolic preparation was chosen because similar to that used in folk medicine against cancer and proposed, even on the online market, without scientific evidence of effectiveness.

\subsubsection{Quantitative Detection of Aloin and Aloe-Emodin in the Extracts}

To determine the aloin and aloe-emodin contents, both the extracts were analyzed with an HPLC instrument (Waters, Milan, Italy); exemplificative chromatograms are reported in Figure S2. The HPLC analysis showed that aloin is the component in the highest quantity in both extracts, as reported in Table 1. Moreover, the levels of aloin were the same in the two extracts, whereas the content of aloe-emodin was significantly lower in the hydroalcoholic extract. These results suggest that absolute methanol and 5\% v/v ethanol have similar capacity to extract aloin from the lyophilized leaves, whereas aloe-emodin can be isolated from plant tissue to a higher quantity using methanol. The estimated aloin and aloe-emodin levels are respectively $0.1 \% w / w$ and $0.001 \% w / w$ of fresh $A$. arborescens leaves.

Table 1. Aloin and aloe-emodin contents in A. arborescens leaf extracts.

\begin{tabular}{ccccc}
\hline Aloe arborescens Leaves & $\begin{array}{c}\text { Aloin } \\
\boldsymbol{\mu g} / \mathbf{m g} \S\end{array}$ & $\begin{array}{c}\text { Aloe-emodin } \\
\boldsymbol{\mu g} / \mathbf{m g} \S\end{array}$ & $\begin{array}{c}\text { Aloin } \\
\mathbf{m g} / \mathbf{1 0 0} \mathbf{~ g ~ F W ~}\end{array}$ & $\begin{array}{c}\text { Aloe-emodin } \\
\mathbf{m g} / \mathbf{1 0 0} \mathbf{g ~ F W}^{\text {a }}\end{array}$ \\
\hline Methanolic extract & $20.0 \pm 1.2$ & $0.22^{*} \pm 0.1$ & $96.7 \pm 5.6$ & $1.07 \pm 0.05$ \\
Hydroalcoholic extract & $21.9 \pm 1.7$ & $0.08 \pm 0.1$ & $106.1 \pm 8.1$ & $0.39 \pm 0.01$ \\
\hline
\end{tabular}

\$: dry extract; ${ }^{a}$ : fresh weight of leaf homogenate; ${ }^{*} p<0.05$ vs. aloe-emodin in the hydroalcoholic extract.

\subsubsection{Determination of Total Phenolic Content (TPC) and Total Flavonoid Content (TFC)}

The TPC and TFC amounts were detected in both the methanolic and the hydroalcoholic extracts as reported in Table 2 . The hydroalcoholic extract is characterized by a higher phenolic amount $(16.8 \mu \mathrm{g}$ gallic acid equivalents (GAE)/mg) compared to the methanolic extract (13.9 $\mu \mathrm{g} \mathrm{GAE} / \mathrm{mg})$, while the flavonoid levels were similar in the two products. Thus, the $5 \% v / v$ ethanol/water solvent seems more suitable for phenolic extraction than methanol, while the use of the two different solvents did not change the amount of flavonoids extracted.

Table 2. Total phenolic and flavonoid contents of Aloe arborescens leaf extracts.

\begin{tabular}{ccccc}
\hline $\begin{array}{c}\text { Aloe arborescens } \\
\text { Leaves }\end{array}$ & GAE & TPC & \multicolumn{2}{c}{ TFC } \\
& $\mu \mathrm{g} / \mathbf{m g}$ & $\mathbf{m g} / \mathbf{1 0 0} \mathbf{g}$ FW & $\begin{array}{c}\text { QE } \\
\boldsymbol{\mu g} / \mathbf{m g}\end{array}$ & $\begin{array}{c}\text { QE } \\
\mathbf{m g} / \mathbf{1 0 0} \mathbf{g} \text { FW }\end{array}$ \\
\hline Methanolic extract & $13.85 \pm 0.46^{*}$ & $67.11 \pm 2.31$ & $3.42 \pm 0.14$ & $16.53 \pm 0.68$ \\
Hydroalcoholic extract & $16.84 \pm 0.77$ & $81.43 \pm 3.71$ & $3.09 \pm 0.17$ & $14.93 \pm 0.83$ \\
\hline
\end{tabular}

TPC: total phenolic content; TFC: total flavonoid content; GAE: gallic acid equivalents; QE: quercetin equivalents; FW: fresh weight of leaf homogenate. ${ }^{*} p<0.05$ vs. GAE in the hydroalcoholic extract.

\subsection{Potential Antidiabetic Activities of Methanolic and Hydroalcoholic Extracts, Aloin, and Aloe-Emodin}

To study the potential antidiabetic property of $A$. arborescens extracts, the antiglycation activity was estimated using the BSA assay and, further, an antiradical assay was performed. 


\subsubsection{Bovine Serum Albumin (BSA) Assay}

BSA assay was performed to study the capacity to reduce the AGE formation of aloin, aloe-emodin, and the methanolic and hydroalcoholic extracts. Aloin and aloe-emodin were studied in the concentration range of 5-50 $\mu \mathrm{M}$, showing a similar trend; both the anthraquinones significantly decreased the glycated albumin at the concentration of $25 \mu \mathrm{M}$ (see Figure 2). Aloin and aloe-emodin at $50 \mu \mathrm{M}$ reduced glycation by $12.8 \%$ and $19.5 \%$, respectively. Likewise, the two extracts significantly inhibited the glycation; the effect became significant at the concentration of $500 \mu \mathrm{g} / \mathrm{mL}$. The methanolic extract showed the highest activity, reducing glycation by $39.5 \%$ at the concentration of $1 \mathrm{mg} / \mathrm{mL}$. Instead, the hydroalcoholic extract, at the same concentration, reduced glycated BSA only by $17.3 \%$.

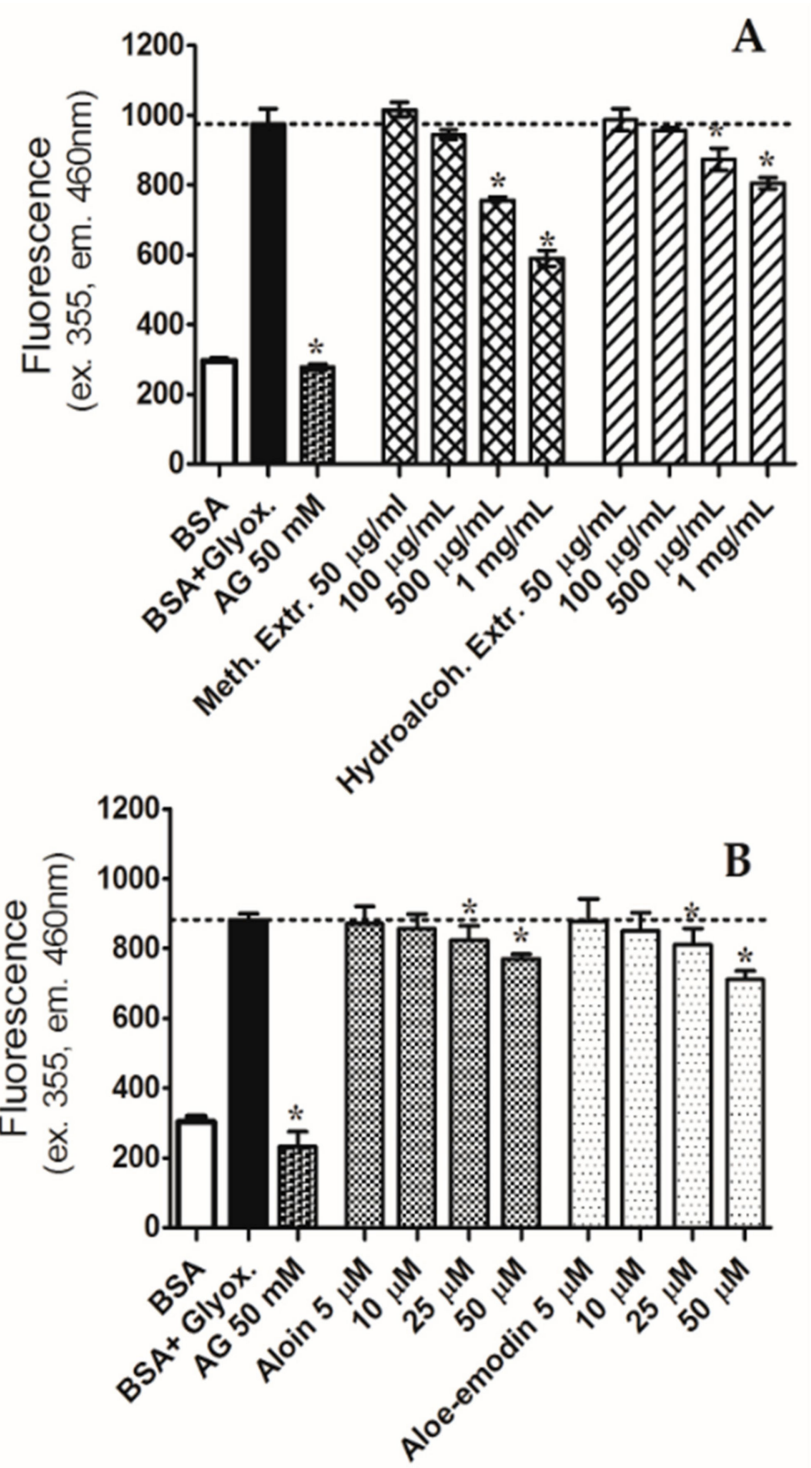

Figure 2. Effects of the methanolic (Meth.) and hydroalcoholic (Hydroalcoh.) A. arborescens extracts (A), and aloin and aloe-emodin (B) against bovine serum albumin (BSA) glycation after seven days of incubation with glyoxal (Glyox.) $0.4 \mathrm{mg} / \mathrm{mL}$. Aminoguanidine (AG) was used as positive control. Extr: extract. ${ }^{*} p<0.05$ vs. BSA plus glyoxal.

\subsubsection{DPPH Assay}

The free-radical scavenging activity of aloin, aloe-emodin, and the two extracts was detected with DPPH assay based on the single electron transfer (SET) mechanism; it is an easy method, largely used to study antioxidant activity [16]. Ascorbic acid and quercetin were used as positive controls. As shown 
in Figure 3, aloin and aloe-emodin exhibited weak scavenging effects, $20 \%$ inhibitory concentration $\left(\mathrm{IC}_{20}\right)>0.5 \mathrm{mM}$, whereas both the methanolic and the hydroalcoholic extracts showed significant DPPH radical scavenging effects; at the concentration of $1 \mathrm{mg} / \mathrm{mL}$, quenching activities were respectively of $51.5 \pm 3.2 \%$ and $64.0 \pm 2.9 \%$; the estimated half maximal inhibitory concentration $\left(\mathrm{IC}_{50}\right)$ values were $1.0 \mathrm{mg} / \mathrm{mL}$ and $0.66 \mathrm{mg} / \mathrm{mL}(p<0.05)$, respectively. These results suggest that the antiradical activities of the extracts are likely not due to the presence of the two anthraquinones because these ones showed only very slight activity.
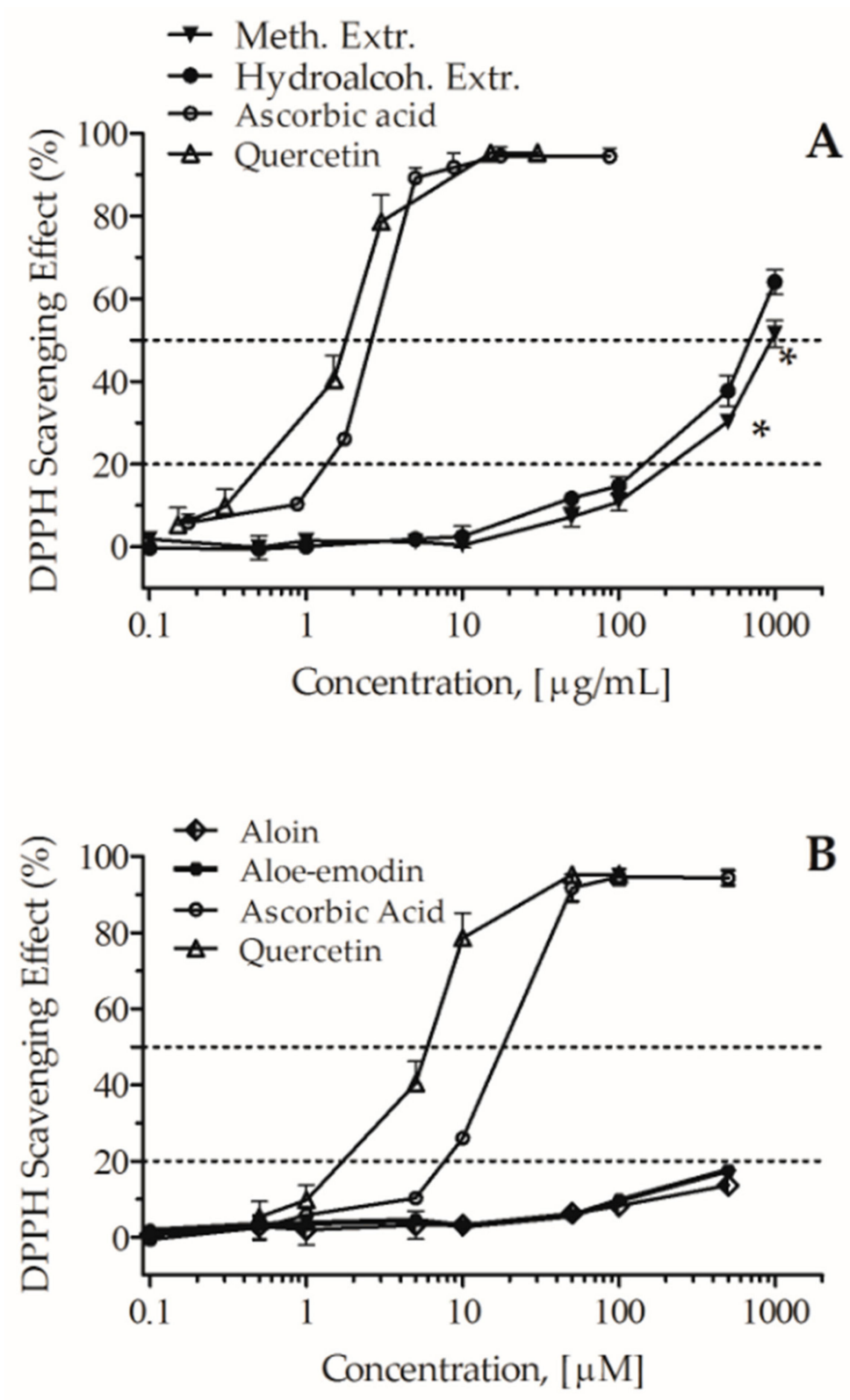

Figure 3. Antiradical activity of the methanolic (Meth.) and hydroalcoholic (Hydroalcoh.) A. arborescens extracts (A), and aloin and aloe-emodin (B). Ascorbic acid and quercetin were used as positive controls. Extr: extract. ${ }^{*} p<0.05$ vs. hydroalcoholic extract.

\subsection{Influence of Methanolic and Hydroalcoholic Extracts, Aloin, and Aloe-Emodin on HT-29 Cells Vitality}

Since authors evidenced similar protein expression in the HT-29 cell line and human intestinal epithelium [17], this cell line was used to assess the influence of the extracts and single compounds on cellular vitality. 


\section{MTT Assay}

The influence of $0.1-50 \mu \mathrm{M}$ aloin and aloe-emodin and $0.1 \mu \mathrm{g} / \mathrm{mL}-1.0 \mathrm{mg} / \mathrm{mL}$ extracts on HT-29 cells viability after $24 \mathrm{~h}$ of incubation was studied. Paclitaxel (Sigma-Aldrich, Milan, Italy) was used as positive control. Aloe-emodin significantly reduces cellular viability from $10 \mu \mathrm{M}$ while aloin was active only at $50 \mu \mathrm{M}$, as reported in Figure 4. The calculated $\mathrm{IC}_{50}$ value of aloe-emodin is $42.1 \mu \mathrm{M}$; thus, it manifested cytotoxic effects even though not comparable with the activity of paclitaxel, a well-known anticancer drug. On the other hand, neither of the two extracts showed cytotoxic effects even at the concentration of $1.0 \mathrm{mg} / \mathrm{mL}$. It is possible to argue that neither the methanol nor the hydroalcoholic extract affect the viability of the HT-29 cell line.
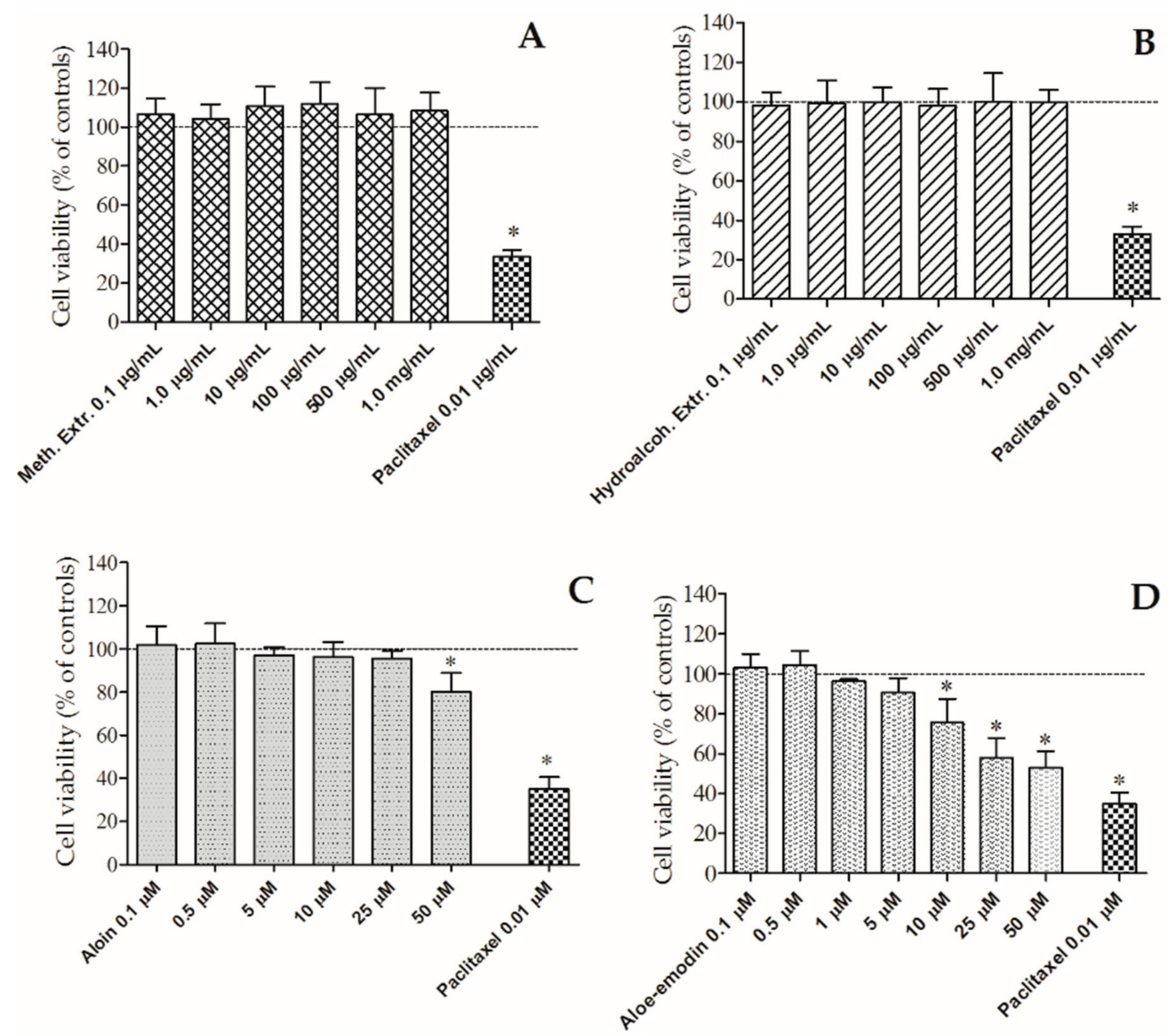

Figure 4. Activity of the methanolic (Meth.) (A) and hydroalcoholic (Hydroalcoh.) (B) extracts, and aloin (C) and aloe-emodin (D) on cellular viability of human colon adenocarcinoma (HT-29) cells. Paclitaxel was used as positive control. Extr: extract. ${ }^{*} p<0.05$ vs. controls (cell viability without treatment).

\subsection{Cellular Uptake of Aloin and Aloe-Emodin}

To evaluate the potential bioavailability of aloin and Aloe-emodin, the capacity of the two anthraquinones to pass into the cells through the cellular membranes was detected.

\section{Cellular Uptake in HT-29 Cells}

The cellular permeability of aloin and aloe-emodin was evaluated using an original experimental protocol; each anthraquinone was added to the cellular medium at the concentration of $5 \mu \mathrm{M}$ and 
incubated for $3 \mathrm{~h}$ in cultured HT-29 cells. The amounts of each compound were then assessed in the extra- and the intracellular compartments, as reported in Table 3. After incubation, the extracellular concentrations of aloin and aloe-emodin were of 4.12 and $0.15 \mu \mathrm{M}$, respectively, while the intracellular amount of aloe-emodin was of $\sim 0.20 \mathrm{nmol} / \mathrm{mg}$. In fact, aloin was not detected in the intracellular solution. The intracellular concentration of aloe-emodin was about $1 / 5$ of the initial quantity. From these results, it is possible to conclude that this compound is able to pass, at least in part, the cellular membranes. On the other hand, the detection of aloin only in the extracellular environment suggests that this molecule cannot permeate cellular membranes. The differences between the initial concentrations and those measured in the intra- and the extracellular samples for both substances lead to the hypothesis that the two compounds were in part metabolized during the time of incubation. The HPLC-DAD analysis supported this observation because chromatograms confirm the presence of various peaks which may refer to unknown metabolites (Figure S3). Further, some biases for example due to compound sequestration from non-specific binding sites or other types of interactions may have occurred.

Table 3. The extra- and the intracellular amounts of aloin and aloe-emodin in HT-29 cells in culture.

\begin{tabular}{cccc}
\hline $\begin{array}{c}\text { Aloe arborescens } \\
\text { Anthraquinones }\end{array}$ & $\begin{array}{c}\text { Concentration } \\
\text { Inoculated }\end{array}$ & $\begin{array}{c}\text { Intracellular } \\
\text { Concentration }\end{array}$ & $\begin{array}{c}\text { Extracellular } \\
\text { Concentration }\end{array}$ \\
\hline Aloin & $5 \mu \mathrm{M}$ & $*$ & $4.12 \mu \mathrm{M}$ \\
Aloe-emodin & $5 \mu \mathrm{M}$ & $0.20 \mathrm{nmol} / \mathrm{mg}(\sim 1.0 \mu \mathrm{M})$ & $0.15 \mu \mathrm{M}$ \\
\hline
\end{tabular}

Each anthraquinone was incubated in human colon adenocarcinoma (HT-29) cells, for $3 \mathrm{~h}$ at $37^{\circ} \mathrm{C}$; then extra-and intracellular amounts were detected with high performance liquid chromatography analysis. * not detectable.

\section{Discussion}

A. arborescens is a medicinal plant of great interest in medicine both as herbal remedy and as source of isolated compounds such as aloin and aloe-emodin. On this subject, several studies are present in the literature but the consensus on its use is elusive and further studies are useful to define its actual role as medicinal plant. In this context, this study investigated two extracts obtained from the whole leaves of $A$. arborescens and their two characteristic components aloin and aloe-emodin. The total flavonoid and phenolic contents of extracts were detected and, with HPLC analysis, the identification and quantification of the two anthraquinones in each extract were performed. The antiradical and antiglycation properties of the extracts, aloin, and aloe-emodin were assessed; further, their influence on cell vitality was studied. Finally, the capacity of aloin and aloe-emodin to cross cellular membranes was evaluated in HT-29 cells, used as model of intestinal layer.

In general, among phenols, aloin and aloe-emodin are distinctive compounds of Aloe extracts often used as phytochemical markers; concerning this genus, the average content of aloin is high in A. arborescens [18]. In both extracts, the aloin quantity detected was about $20 \mathrm{mg} / \mathrm{g}$ in lyophilized leaves, and $0.1 \% \mathrm{p} / \mathrm{p}$ in fresh leaves. Moreover, the aloe-emodin content was always considerably lower than the aloin level, and also was significantly lower in the hydroalcoholic extract compared to the methanolic one, as reported in Table 1. In the literature few studies are published on this topic; recently, authors reported that the amount of aloin was of $2.9 \% p / p$ in $A$. arborescens leaf exudate (which is a more concentrated preparation) [18]. Overall, other studies reported very low or even no amounts of aloe-emodin in extracts of different Aloe species [19], as well as of A. arborescens [18].

Aloin is the C-glucoside of aloe-emodin anthrone and it is present in nature as two diastereomers, aloin A and aloin B, as reported in the HPLC chromatogram in Figure S2. It is of interest to note that aloin is a marker used to identify Aloe spp. [20]. Even if aloin is known as a laxative agent [21], nowadays new pharmacological properties are being investigated. A recent study supports the anticancer activity of aloin, showing that it was able to induce apoptosis of A549 cells [22]. Further, other authors demonstrated that the treatment of bone marrow-derived mesenchymal stem cells with aloin affects bone metabolism and promotes osteogenic differentiation, enhancing mineralization and 
alkaline phosphatase activity and involving the ERK1/2-Runx2 signaling pathway [23]. Regarding aloe-emodin, in vitro studies have evidenced various properties like antiplatelet [24] and anticancer activities [25].

Studies on the potential activity of plant extracts or isolated compounds against AGE formation could discover new agents with antiglycation activity useful in the prevention of hyperglycemic damage. Since glycated albumin is associated with diabetic complications [26], the BSA assay is a valuable test to assess the potential antidiabetic property of products. The present results showed significant antiglycation activities of both methanolic and hydroalcoholic $A$. arborescens extracts at the concentration of $500 \mu \mathrm{g} / \mathrm{mL}$. The isolated compounds aloin and aloe-emodin reduced albumin glycation from the concentration of $25 \mu \mathrm{M}$. Very few data are available on effects induced by Aloe and its constituents on protein glycation; aloe-emodin and Aloe sinkatana extracts decreased protein-sugar reactions, even if aloe-emodin exhibited only weak activity in BSA-glucose assay, with an $\mathrm{IC}_{50}$ of $517 \mu \mathrm{M}$ [27]. Other authors suggested that Aloe vera and aloin could protect the enzyme superoxide dismutase against the structural changes induced by glycation [28]. Previously, a protective role of A. arborescens was observed on islets of Langerhans in mice and an inhibitory effect was measured on the jejunal glucose absorption [29]. Even if the scientific literature reports several articles on Aloe species and antidiabetic activity, no studies have reported on $A$. arborescens and protein glycation damage. Thus, the present data show for the first time the antiglycation activity of $A$. arborescens leaf extracts.

Due to the strong relationship between glycation and oxidative stress, one being the cause of the other [30], the antioxidant properties of the two extracts and aloin and aloe-emodin were evaluated with DPPH assay. Both extracts evidenced a concentration-dependent antiradical activity, which was significant from $50 \mu \mathrm{g} / \mathrm{mL}$, while the single anthraquinones showed very low activity. Recently, studies reported a fair antioxidant activity of $A$. arborescens extracts compared with other Aloe species [18], in particular against the oxygen radicals [31]. In agreement with the present results, the relatively small contribution of aloin and in general of anthraquinones to the overall radical scavenging activity has been reported also by other researchers [32-34]. Several authors ascribe the antiradical activity of plant extracts to the presence of phenols; thus, we detected the phenols and flavonoids amounts in the extracts. The hydroalcoholic extract had a higher phenolic amount $(16.8 \mu \mathrm{g} \mathrm{GAE} / \mathrm{mg})$ than the methanolic extract $(13.9 \mu \mathrm{g} \mathrm{GAE} / \mathrm{mg}$ ), suggesting that the $5 \% v / v$ ethanol/water solvent can be considered a suitable solvent for the extraction of phenols from Aloe leaves. Overall, phenolic compounds are generally linked with health benefits, for example in cardiovascular diseases and cancer, and their presence is deemed helpful for disease prevention [35,36].

Moving from in vitro to in vivo, one of the critical points is the bioavailability of the studied compounds. The HT-29 cell line, obtained from human colorectal adenocarcinoma, is a suitable model for bioavailability measurements thanks to its similarities, both in phenotype and enzymatic expression, with mature intestinal cells like enterocytes [17]. In the present investigation, firstly the potential cytotoxicity was evaluated. The two extracts did not show any cytotoxic activity up to $1 \mathrm{mg} / \mathrm{mL}$, while aloin and aloe-emodin significantly reduced cell viability respectively from $50 \mu \mathrm{M}$ and $10 \mu \mathrm{M}$. In details, aloe-emodin was the most active, causing a concentration-dependent inhibition in the range of 10-50 $\mu \mathrm{M}$; at $10 \mu \mathrm{M}$ aloe-emodin reduced vitality to $75.6 \%$. In agreement with these findings, authors [37] showed that aloe-emodin inhibited HT-29 viability in a concentration- and time-dependent manner, reducing it to $82.8 \%$ after $24 \mathrm{~h}$ of treatment at $10 \mu \mathrm{M}$. Other authors showed anticancer activities of aloe-emodin in different cell lines, like U87MG from human glioblastoma and T24 from human bladder cancer $[38,39]$. Some studies showed that also aloin exerts anticancer properties, inhibiting both cell proliferation and angiogenesis. In detail, aloin was able to decrease the vascular endothelial growth factor (VEGF)-induced viability of human umbilical vein endothelial cells (HUVECs) from the concentration of $10 \mu \mathrm{M}$ which was not cytotoxic in the same cell line, under normal conditions. A direct measurement in colorectal cancer cell lines showed an inhibitory effect on cell viability with an $\mathrm{IC}_{50}$ of $200-240 \mu \mathrm{mol} / \mathrm{L}$ [40]. 
Although HT-29 cells are a useful model of human enterocytes, these may behave differently from human intestinal mucosa cells [17]. However, an estimation of oral bioavailability of aloe-emodin and aloin can be obtain via cellular uptake assay using HT-29 cells [17]. Aloin and aloe-emodin $5 \mu \mathrm{M}$, incubated for $3 \mathrm{~h}$ in HT-29 cells, were assessed both in the extra- and the intracellular compartments. Aloin was almost totally found in the extracellular solution $(4.12 \mu \mathrm{M})$ whereas it was not detected in the intracellular compartment. On the contrary, aloe-emodin was detected in a very low amount in the extracellular solution $(0.15 \mu \mathrm{M})$, whereas a significantly higher amount was found at the intracellular level: $0.20 \mathrm{nmol} / \mathrm{mg}$ protein—about $1 \mu \mathrm{M}$. These results show that only aloe-emodin can pass through cellular membranes into the cells. Thus, it could be concluded that aloe-emodin has higher bioavailability than its C-glycosyl compound aloin. However, further in vitro assessments, e.g., using intestinal epithelial cell monolayers, and also in vivo studies are necessary to evaluate aloe-emodin and aloin bioavailability. Previously, other authors studied the cellular uptake of aloe-emodin into a human breast adenocarcinoma cell line (MCF-7) at $5 \mu \mathrm{M}$ with a $24 \mathrm{~h}$ incubation, showing an intracellular uptake of $1.4 \mu \mathrm{g} / \mathrm{mg}$ protein [41]. Moreover, in agreement with present results, other authors compared the aloin and aloe-emodin uptake in the Caco- 2 cell monolayer and everted gut sac model, showing that the absorption rate of aloe-emodin is always higher than those of aloin [42]. Different mechanisms of transport are suggested for the two molecules. Since aloe-emodin is an aglycone, it could permeate membranes through passive diffusion, while aloin uptake requires glucose transporters like sodium-dependent glucose co-transporter (SGLT1) and GLUT2 glucose transporter [43]. Not only transportation but also metabolism may affect the bioavailability of the anthraquinones in vivo. Altogether, the literature and the present experimental data suggest that aloin may be metabolized into aloe-emodin in the intestine and then absorbed into the bloodstream, giving also systemic effects. Pharmacokinetic studies carried out in rats showed that intraperitoneal administration of aloe-emodin at $7.5 \mathrm{mg} / \mathrm{kg}$ daily for six days determined higher biodistribution into tissues with rich blood supply such as the spleen, lung, heart, and liver [41]. Recently, authors showed in high-fat-fed rats treated with $100 \mathrm{mg} / \mathrm{kg}$ aloe-emodin intragastrically administered each day for six weeks, significant antiarrhythmic effects, preventing QT prolongation [44].

\section{Materials and Methods}

\subsection{Extract Preparation}

Mature leaves from 42 month-old plants were collected in the month of June 2016 from a northern Italy cultivation (Manerba del Garda, Brescia). A dried sample of leaves is deposited at the Department of Pharmaceutical and Pharmacological Sciences, Laboratory of Pharmacognosy, with the voucher number of AA-BS-011. The leaves were cut to the base and cleaned with a wet cloth, while the side thorns were removed. Subsequently, leaves were subdivided into small pieces to be homogenized in a mixer, obtaining $463 \mathrm{~g}$ of product which was then lyophilized up to complete dehydration with a freeze dryer (E2M18 Edwards, UK). The freeze-dried product was stored at $-20{ }^{\circ} \mathrm{C}$. To obtain the two extracts, a weighed part of product was soaked in methanol or in $5 \% v / v$ ethanol for $1 \mathrm{~h}$; then, each solution was filtered and stored at $4{ }^{\circ} \mathrm{C}$ in the dark, and used within five days. The stability of solutions during the days was tested with TPC and TFC assays and the quantitative detection of aloin and aloe-emodin contents with HPLC analysis.

\subsection{High Performance Liquid Chromatography (HPLC-DAD) Analysis}

Chromatographic analyses were carried out by the HPLC instrument (Waters Corporation, Milan, Italy) equipped with 1525 Binary HPLC pump (Waters Corporation, Milan, Italy) and 2998 Photodiode Array Detector (Waters Corporation, Milan, Italy). The chromatographic separation was performed with a Symmetry $囚 R P C 18,4.6 \times 75 \mathrm{~mm}, 3.5 \mu \mathrm{m}$ column (Waters Corporation, Milan, Italy). The method was modified from that of [20]; a linear methanolic gradient from 20 to $80 \% v / v$ in $15 \mathrm{~min}$ (A: water with acetic acid $0.5 \% v / v$, and B: methanol with acetic acid $0.5 \% v / v)$, with a flow rate of $1 \mathrm{~mL} / \mathrm{min}$ was applied. 
Peaks were detected in the range of $210-400 \mathrm{~nm}$. All samples were filtered by membrane filters $(0.22-\mu \mathrm{m}$ pore size, Millipore, Burlington, MA, USA) and then injected (10 $\mu \mathrm{L})$. The compound identification was performed on the basis of retention time and spectral matching with aloin and aloe-emodin standards. To improve the qualitative and quantitative identification of aloin and aloe-emodin in the two extracts, in a set of analyses a precise amount of each standard was co-injected with each extract for the HPLC detection. These ones confirmed the retention time of 9.5 and 9.8 min for aloin B and A, respectively, and of 12.3 min for aloe-emodin, as reported in Figure S2. For the preparation of the calibration curves, standard stock solutions were prepared in methanol, filtered and appropriately diluted to obtain the desired concentrations $(1.0,5.0,10.0$, and $20.0 \mu \mathrm{M})$. The calibration graphs were plotted as the linear regression of the peak areas versus concentrations. To determine the aloin and aloe-emodin contents, both extracts were analyzed with HPLC-DAD instrument by injection of each extract, at the concentration of $1 \mathrm{mg} / \mathrm{mL}$. The amount of each compound in extra- and intracellular solutions was calculated comparing the results with the standard calibration curves. The last step included the analysis of the lysate protein content using the Lowry protein assay [45], to obtain the final results expressed as nmol of aloin or aloe-emodin per mg of protein.

\subsection{Determination of Total Phenolic Content (TPC) and Total Flavonoid Content (TFC)}

TPC was determined using the Folin-Ciocalteu reagent according to the method previously described [46]. TPC of each extract is expressed as $\mu \mathrm{g}$ of gallic acid equivalents (GAE) per $\mathrm{g}$ of freeze-dried product or as mg of gallic acid equivalents (GAE) per $100 \mathrm{~g}$ of fresh-weight (FW) product. TFC was detected by aluminum chloride $\left(\mathrm{AlCl}_{3}\right)$ colorimetric method [47] and expressed as $\mu \mathrm{g}$ of quercetin equivalents $(\mathrm{QE})$ per $\mathrm{g}$ of freeze-dried product or as $\mathrm{mg}$ of quercetin equivalents $(\mathrm{QE})$ per $100 \mathrm{~g}$ of fresh-weight (FW) product.

\subsection{DPPH Assay}

The free radical-scavenging activity of samples was measured by 1,1-diphenyl-2-picryl-hydrazil $(\mathrm{DPPH})$ method [48]. Samples solutions were prepared and added to $70 \mu \mathrm{M} \mathrm{DPPH}$; the mixtures were kept in the dark for $60 \mathrm{~min}$, and the absorbance was read at $517 \mathrm{~nm}$ using a Beckman Coulter DU 8005 spectrophotometer (Fullerton, CA, USA). The antiradical curves were obtained with different sample concentrations. Radical scavenging capacity is expressed as percentage effect $(\mathrm{E} \%)$.

\subsection{Bovine Serum Albumin (BSA) Assay}

The preparation of glycated BSA was performed according to a previously described method, with minor modifications [49]. Shortly, AGEs, which are the product of glycation, were determined using BSA, as protein substrate, and glyoxal, as glycating agent. The solutions of substrates were added with each extract $(50,100,500$, and $1000 \mu \mathrm{g} / \mathrm{mL})$, or aloe-emodin or aloin $(5,10,25$ and $50 \mu \mathrm{M})$, and incubated at $37^{\circ} \mathrm{C}$ for 7 days. After that time, the fluorescence measurement allows the calculation of glycation inhibition as per cent difference between control condition and glycation in the presence of the samples. Aminoguanidine (50 mM, AG) was used as positive control.

\subsection{3-[4,5-Dimethylthiazol-2-yl]-2,5 Diphenyl Tetrazolium Bromide (MTT) Assay}

The cellular viability after the treatment with the selected compounds or the extracts was assessed with the MTT assay [50]. HT-29 cells were seeded in a 96-well plate at the density of 5000 cells in each well and let grow overnight; the day after cells were treated with different concentrations of each substance and after $24 \mathrm{~h}$ an aliquot of MTT solution was added to each well, reaching the final concentration of $500 \mu \mathrm{g} / \mathrm{mL}$. After the reduction of the MTT by cellular enzymes, the medium was removed and the insoluble formazan salts were solubilized with an acid solution of 2-propanol. The absorbance of each purple formazan solution was measured using a Victor multilabel plate reader (PerkinElmer, MA, USA), setting the wavelength at $520 \mathrm{~nm}$. 


\subsection{Cellular HT-29 Uptake Assay}

To assess the aloin and aloe-emodin cellular uptake, the human colon adenocarcinoma cells (HT-29) were seeded in 6-well plates in complete medium and let grow until confluence for $48 \mathrm{~h}$. Then, culture medium was removed and cells were washed with PBS and treated for $3 \mathrm{~h}$ with $5 \mu \mathrm{M}$ aloin or aloe-emodin. After the incubation, an aliquot of the extracellular solution was taken from each well and stored at $-20^{\circ} \mathrm{C}$ for further analysis. Then the medium was removed, cells were washed two times with PBS and prepared for the following steps: (1) protein quantification, where cells were lysed with $200 \mu \mathrm{L}$ of lysis buffer and wells were washed with $200 \mu \mathrm{L}$ of PBS; and (2) cellular uptake evaluation, where cells were collected gently scraping with PBS, centrifuged at $1250 \mathrm{rpm}$ for $5 \mathrm{~min}$, and added to $500 \mu \mathrm{L}$ of $80 \% v / v$ methanolic solution in water/ $0.1 \% v / v$ acetic acid to extract the intracellular content. The samples were maintained in ice for $15 \mathrm{~min}$, then sonicated and centrifuged at 10,000 rpm for $10 \mathrm{~min}$. The precipitated proteins were excluded, while the supernatant solutions were collected for chromatographic analysis. The lysates and the intracellular solutions were stored at $-20^{\circ} \mathrm{C}$ for the HPLC-DAD analysis.

\subsection{Statistical Analysis}

Data are expressed as mean \pm SEM of at least three experiments. The experimental data were graphed and analyzed using GraphPad Prism 5 (San Diego, CA, USA), and the half maximal inhibitory concentration $\left(\mathrm{IC}_{50}\right)$ values were calculated [51]. The differences between control and treatment were assessed by Student's $t$ test. The level of significance was set at $p<0.05$.

\section{Conclusions}

This research shows that both the methanolic and the hydroalcoholic A. arborescens leaf extracts have antiglycation and antiradical activities which could be ascribable to their phenolic components, and only in part to aloin and aloe-emodin. These two anthraquinones show moderate inhibitory activities on cell viability, whereas the two extracts completely lack cytotoxicity. Further, the capability of aloe-emodin to be absorbed into the cells was evidenced. Overall, the data from this research support the helpfulness of using $A$. arborescens leaf extracts against hyperglycemia-associated diseases.

Supplementary Materials: The following are available online at http://www.mdpi.com/1420-3049/24/11/2128/s1, Figure S1: Aloe arborescens, Figure S2: Aloe-emodin: cellular uptake.

Author Contributions: Conceptualization, G.F.; Investigation, F.B. and E.M.; Writing-Original Draft Preparation, G.F.; Writing-Review and Editing, G.F. and M.G.; Funding Acquisition, G.F.

Funding: This work was supported by DOR 2016-2018.

Conflicts of Interest: The authors declare no conflict of interest.

\section{References}

1. Salehi, B.; Albayrak, S.; Antolak, H.; Kregiel, D.; Pawlikowska, E.; Sharifi-Rad, M.; Uprety, Y.; Tsouh Fokou, P.; Yousef, Z.; Amiruddin Zakaria, Z.; et al. Aloe Genus Plants: From Farm to Food Applications and Phytopharmacotherapy. Int. J. Mol. Sci. 2018, 19, 2843. [CrossRef] [PubMed]

2. Amoo, S.O.; Aremu, A.O.; Van Staden, J. Unraveling the medicinal potential of South African Aloe species. J. Ethnopharmacol. 2014, 153, 19-41. [CrossRef] [PubMed]

3. Bastian, P.; Fal, A.M.; Jambor, J.; Michalak, A.; Noster, B.; Sievers, H.; Steuber, A.; Walas-Marcinek, N. Candelabra aloe (Aloe arborescens) in the therapy and prophylaxis of upper respiratory tract infections: Traditional use and recent research results. Wien. Med. Wochenschr. 2013, 163, 73-79. [CrossRef] [PubMed]

4. Nazeam, J.A.; Gad, H.A.; El-Hefnawy, H.M.; Singab, A.B. Chromatographic separation and detection methods of Aloe arborescens Miller constituents: A systematic review. J. Chromatogr. Anal. Technol. Biomed. Life Sci. 2017, 1058, 57-67. [CrossRef] [PubMed] 
5. Trinh, P.T.N.; Luan, N.Q.; Tri, M.D.; Khanh, V.D.; An, N.H.; Minh, P.N.; An, P.N.; Thuy, N.T.L.; Phung, N.K.P.; Dung, L.T. New naphthalene derivative from the leaves of Cassia grandis L. Nat. Prod. Res. 2017, 31, 1733-1738. [CrossRef]

6. Groom, Q.J.; Reynolds, T. Barbaloin in Aloe species. Planta Med. 1987, 53, 345-348. [CrossRef] [PubMed]

7. Arosio, B.; Gagliano, N.; Fusaro, L.M.; Parmeggiani, L.; Tagliabue, J.; Galetti, P.; De Castri, D.; Moscheni, C.; Annoni, G. Aloe-Emodin quinone pretreatment reduces acute liver injury induced by carbon tetrachloride. Pharmacol. Toxicol. 2000, 87, 229-233. [CrossRef]

8. Madonna, R.; Pieragostino, D.; Balistreri, C.R.; Rossi, C.; Geng, Y.-J.; Del Boccio, P.; De Caterina, R. Diabetic macroangiopathy: Pathogenetic insights and novel therapeutic approaches with focus on high glucose-mediated vascular damage. Vascul. Pharmacol. 2018. [CrossRef]

9. Lissoni, P.; Rovelli, F.; Brivio, F.; Zago, R.; Colciago, M.; Messina, G.; Mora, A.; Porro, G. A randomized study of chemotherapy versus biochemotherapy with chemotherapy plus Aloe arborescens in patients with metastatic cancer. In Vivo 2009, 23, 171-175.

10. Lee, H.-Z.Z.; Hsu, S.-L.L.; Liu, M.-C.C.; Wu, C.-H.H. Effects and mechanisms of aloe-emodin on cell death in human lung squamous cell carcinoma. Eur. J. Pharmacol. 2001, 431, 287-295. [CrossRef]

11. Lin, H.D.; Li, K.T.; Duan, Q.Q.; Chen, Q.; Tian, S.; Chu, E.S.M.; Bai, D.Q. The effect of aloe-emodin-induced photodynamic activity on the apoptosis of human gastric cancer cells: A pilot study. Oncol. Lett. 2017, 13, 3431-3436. [CrossRef] [PubMed]

12. Pecere, T.; Sarinella, F.; Salata, C.; Gatto, B.; Bet, A.; Vecchia, F.D.; Diaspro, A.; Carli, M.; Palumbo, M.; Palu, G. Involvement of p53 in specific anti-neuroectodermal tumor activity of aloe-emodin. Int. J. Cancer 2003, 106, 836-847. [CrossRef] [PubMed]

13. Liu, K.; Park, C.; Li, S.; Lee, K.W.; Liu, H.; He, L.; Soung, N.K.; Ahn, J.S.; Bode, A.M.; Dong, Z.; et al. Aloe-emodin suppresses prostate cancer by targeting the mTOR complex 2. Carcinogenesis 2012, 33, 1406-1411. [CrossRef] [PubMed]

14. Pecere, T.; Gazzola, M.V.; Mucignat, C.; Parolin, C.; Vecchia, F.D.; Cavaggioni, A.; Basso, G.; Diaspro, A.; Salvato, B.; Carli, M.; et al. Aloe-emodin is a new type of anticancer agent with selective activity against neuroectodermal tumors. Cancer Res. 2000, 60, 2800-2804. [PubMed]

15. Shimpo, K.; Chihara, T.; Kaneko, T.; Beppu, H.; Wakamatsu, K.; Shinzato, M.; Yukitake, J.; Sonoda, S. Inhibitory effects of low-dose aloe-emodin on the development of colorectal tumors in min mice. Asian Pac. J. Cancer Prev. 2014, 15, 5587-5592. [CrossRef] [PubMed]

16. Aruoma, O.I. Methodological considerations for characterizing potential antioxidant actions of bioactive components in plant foods. Mutat. Res. Fundam. Mol. Mech. Mutagen. 2003, 523-524, 9-20. [CrossRef]

17. Martínez-Maqueda, D.; Miralles, B.; Recio, I. The Impact of Food Bioactives on Health. In The Impact of Food Bioactives on Health; Springer: Cham, Switzerland, 2015; pp. 113-124.

18. Cardarelli, M.; Rouphael, Y.; Pellizzoni, M.; Colla, G.; Lucini, L. Profile of bioactive secondary metabolites and antioxidant capacity of leaf exudates from eighteen Aloe species. Ind. Crops Prod. 2017, 108, 44-51. [CrossRef]

19. Kumar, S.; Yadav, M.; Yadav, A.; Rohilla, P.; Yadav, J.P. Antiplasmodial potential and quantification of aloin and aloe-emodin in Aloe vera collected from different climatic regions of India. BMC Complement. Altern. Med. 2017, 17, 1-10. [CrossRef]

20. Zhao, Y.; Sun, Y.N.; Lee, M.J.; Kim, Y.H.; Lee, W.; Kim, K.H.; Kim, K.T.; Kang, J.S. Identification and discrimination of three common Aloe species by high performance liquid chromatography-tandem mass spectrometry coupled with multivariate analysis. J. Chromatogr. B 2016, 1031, 163-171. [CrossRef]

21. Patel, K.; Patel, D.K. Medicinal importance, pharmacological activities, and analytical aspects of aloin: A concise report. J. Acute Dis. 2013, 2, 262-269. [CrossRef]

22. Wan, L.; Zhang, L.; Fan, K.; Wang, J. Aloin promotes A549 cell apoptosis via the reactive oxygen species-mitogen activated protein kinase signaling pathway and p53 phosphorylation. Mol. Med. Rep. 2017, 16, 5759-5768. [CrossRef] [PubMed]

23. Li, P.; Kong, J.; Chen, Z.; Huang, S.; Lv, G.; Wei, B.; Wei, J.; Jing, K.; Quan, J.; Chu, J. Aloin promotes osteogenesis of bone-marrow-derived mesenchymal stem cells via the ERK1/2-dependent Runx2 signaling pathway. J. Nat. Med. 2019, 73, 104-113. [CrossRef] [PubMed] 
24. Furkan, M.; Alam, M.T.; Rizvi, A.; Khan, K.; Ali, A.; Shamsuzzaman; Naeem, A. Aloe emodin, an anthroquinone from Aloe vera acts as an anti aggregatory agent to the thermally aggregated hemoglobin. Spectrochim. Acta Part A Mol. Biomol. Spectrosc. 2017, 179, 188-193. [CrossRef] [PubMed]

25. Özenver, N.; Saeed, M.; Demirezer, L.Ö.; Efferth, T. Aloe-emodin as drug candidate for cancer therapy. Oncotarget 2018, 9, 17770-17796. [CrossRef] [PubMed]

26. Raghav, A.; Ahmad, J.; Alam, K. Impact of glycation on structural and antioxidant function of human serum albumin: Relevance in diabetic complications. Diabetes Metab. Syndr. Clin. Res. Rev. 2016, 10, 96-101. [CrossRef] [PubMed]

27. ELhassan, G.O.M.; Adhikari, A.; Yousuf, S.; Hafizur Rahman, M.; Khalid, A.; Omer, H.; Fun, H.-K.; Jahan, H.; Choudhary, M.I.; Yagi, S. Phytochemistry and antiglycation activity of Aloe sinkatana Reynolds. Phytochem. Lett. 2012, 5, 725-728. [CrossRef]

28. Younus, H.; Anwar, S. Antiglycating activity of Aloe vera gel extract and its active component Aloin. J. Proteins Proteom. 2018, 9, 115-125.

29. Beppu, H.; Shimpo, K.; Chihara, T.; Kaneko, T.; Tamai, I.; Yamaji, S.; Ozaki, S.; Kuzuya, H.; Sonoda, S. Antidiabetic effects of dietary administration of Aloe arborescens Miller components on multiple low-dose streptozotocin-induced diabetes in mice: Investigation on hypoglycemic action and systemic absorption dynamics of aloe components. J. Ethnopharmacol. 2006, 103, 468-477. [CrossRef]

30. Younus, H.; Anwar, S. Prevention of non-enzymatic glycosylation (glycation): Implication in the treatment of diabetic complication. Int. J. Health Sci. 2016, 10, 261-277. [CrossRef]

31. Lai, Q.; Wang, H.; Guo, X.; Abbasi, A.M.; Wang, T.; Li, T.; Fu, X.; Li, J.; Liu, R.H. Comparison of phytochemical profiles, antioxidant and cellular antioxidant activities of seven cultivars of Aloe. Int. J. Food Sci. Technol. 2016, 51, 1489-1494. [CrossRef]

32. Lucini, L.; Pellizzoni, M.; Pellegrino, R.; Molinari, G.P.; Colla, G. Phytochemical constituents and in vitro radical scavenging activity of different Aloe species. Food Chem. 2015, 170, 501-507. [CrossRef] [PubMed]

33. Romani, A.; Vignolini, P.; Isolani, L.; Tombelli, S.; Heimler, D.; Turchetti, B.; Buzzini, P. In vitro radical scaveging and anti-yest activity of extracts from leaves of Aloe species growing in Congo. Nat. Prod. Commun. 2008, 3, 2061-2064.

34. Jeremić, S.; Amić, A.; Stanojević-Pirković, M.; Marković, Z. Selected anthraquinones as potential free radical scavengers and P-glycoprotein inhibitors. Org. Biomol. Chem. 2018, 16, 1890-1902. [CrossRef] [PubMed]

35. Curin, Y.; Andriantsitohaina, R. Polyphenols as potential therapeutical agents against cardiovascular diseases. Pharmacol. Rep. 2005, 57, 97-107.

36. Roleira, F.M.F.; Tavares-da-Silva, E.J.; Varela, C.L.; Costa, S.C.; Silva, T.; Garrido, J.; Borges, F. Plant derived and dietary phenolic antioxidants: Anticancer properties. Food Chem. 2015, 183, 235-258. [CrossRef] [PubMed]

37. Cheng, C.; Dong, W. Aloe-Emodin Induces Endoplasmic Reticulum Stress-Dependent Apoptosis in Colorectal Cancer Cells. Med. Sci. Monit. 2018, 24, 6331-6339. [CrossRef] [PubMed]

38. Arcella, A.; Oliva, M.A.; Staffieri, S.; Sanchez, M.; Madonna, M.; Riozzi, B.; Esposito, V.; Giangaspero, F.; Frati, L. Effects of aloe emodin on U87MG glioblastoma cell growth: In vitro and in vivo study. Environ. Toxicol. 2018, 33, 1160-1167. [CrossRef]

39. Lin, J.-G.; Chen, G.-W.; Li, T.-M.; Chouh, S.-T.; Tan, T.-W.; Chung, J.-G. Aloe-Emodin Induces Apoptosis in T24 Human Bladder Cancer Cells Through the p53 Dependent Apoptotic Pathway. J. Urol. 2006, 175, 343-347. [CrossRef]

40. Pan, Q.; Pan, H.; Lou, H.; Xu, Y.; Tian, L. Inhibition of the angiogenesis and growth of Aloin in human colorectal cancer in vitro and in vivo. Cancer Cell Int. 2013. [CrossRef] [PubMed]

41. Freag, M.S.; Elnaggar, Y.S.R.; Abdelmonsif, D.A.; Abdallah, O.Y. Stealth, biocompatible monoolein-based lyotropic liquid crystalline nanoparticles for enhanced aloe-emodin delivery to breast cancer cells: In vitro and in vivo studies. Int. J. Nanomed. 2016, 11, 4799-4818. [CrossRef] [PubMed]

42. Park, M.-Y.; Kwon, H.-J.; Sung, M.-K. Intestinal absorption of aloin, aloe-emodin, and aloesin; A comparative study using two in vitro absorption models. Nutr. Res. Pract. 2009, 3, 9-14. [CrossRef] [PubMed]

43. Shim, S.M.I.; Kwon, H. assessing absorbability of bioactive components in aloe using In Vitro digestion model with human intestinal cell. J. Food Biochem. 2010, 34, 425-438. [CrossRef] 
44. Bai, Y.; Su, Z.; Sun, H.; Zhao, W.; Chen, X.; Hang, P.; Zhu, W.; Du, Z. Aloe-Emodin Relieves High-Fat Diet Induced QT Prolongation via MiR-1 Inhibition and IK1 Up-Regulation in Rats. Cell. Physiol. Biochem. 2018, 43, 1961-1973. [CrossRef] [PubMed]

45. Lowry, O.H.; Rosebrough, N.J.; Farr, A.L.; Randall, R.J. Protein measurement with the Folin phenol reagent. J. Biol. Chem. 1951, 193, 265-275. [PubMed]

46. Ainsworth, E.A.; Gillespie, K.M. Estimation of total phenolic content and other oxidation substrates in plant tissues using Folin-Ciocalteu reagent. Nat. Protoc. 2007, 2, 875-877. [CrossRef] [PubMed]

47. Chang, C.-C.; Yang, M.-H.; Wen, H.-M. Estimation of total flavonoid content in propolis by two complementary colorimetric methods. J. Food Drug Anal. 2002, 10, 178-182.

48. Brand-Williams, W.; Cuvelier, M.E.; Berset, C. Use of a free radical method to evaluate antioxidant activity. LWT Food Sci. Technol. 1995, 28, 25-30. [CrossRef]

49. Matsuura, N.; Aradate, T.; Sasaki, C.; Kojima, H.; Ohara, M.; Hasegawa, J.; Ubukata, M. Screening system for the maillard reaction inhibitor from natural product extracts. J. Heal. Sci. 2002, 48, 520-526. [CrossRef]

50. Van Meerloo, J.; Kaspers, G.J.L.; Cloos, J. Cell Sensitivity Assays: The MTT Assay. In Methods in Molecular Biology; Humana Press: New York, NY, USA, 2011; Volume 731, pp. 237-245.

51. Chen, Z.; Bertin, R.; Froldi, G. EC50 estimation of antioxidant activity in DPPH* assay using several statistical programs. Food Chem. 2013, 138, 414-420. [CrossRef]

Sample Availability: Samples of AA-BS-011 and AA-BS-011-1 are available from the Laboratory of Pharmacognosy, DSF, University of Padova.

(C) 2019 by the authors. Licensee MDPI, Basel, Switzerland. This article is an open access article distributed under the terms and conditions of the Creative Commons Attribution (CC BY) license (http://creativecommons.org/licenses/by/4.0/). 